\title{
PENGARUH PERTUMBUHAN PENJUALAN,PROFITABILITAS DAN LIKUIDITAS TERHADAP KINERJA HERO SUPERMARKET DI BURSA EFEK INDONESIA
}

\author{
Jhon Nasyaroeka $^{(1)^{*}}$, Rina Milyanti ${ }^{(2)}$ \\ Institut Maritim Prasetiya Mandiri \\ *email: jhonnasyaroeka@gmail.com,rinamilyati@gmail.com
}

\begin{abstract}
Abstrak. Tujuan dari penelitian ini untuk mengetahui pengaruh antara pertumbuhan penjualan ,profitabilitas dan likuiditas terhadap kinerja perusahaan.Objek perusahaan adalah hero supermarket yang terdaftar di bursa efek Indonesia. Populasi yang diambil dalam penelitian ini adalah hero supermarket yang sudah terdaftar di Bursa Efek Indonesia ( BEI ). Sampel yang digunakan perusahaan menggunakan metode pruposive sampling Adapun hasil dari penelitian ini ternyata secara parsial berpengaruh.Hal ini berarti pertumbuhan penjualan,profitabilitas dan likuiditas sangat mempunyai peran yang besar terhadap kinerja perusahaan.
\end{abstract}

Kata Kunci: Pertumbuhan Penjualan, Profitabilitas, Likuiditas, Kinerja

Abstract. Abstract. The purpose of this study is to determine the effect of sales growth, profitability and liquidity on the company's performance. The object of the company is a supermarket hero listed on the Indonesian stock exchange. The population taken in this study is the supermarket hero that has been listed on the Indonesia Stock Exchange (BEI). The sample used by the company using the pruposive sampling method. The results of this study were partially influential. This means that sales growth, profitability and liquidity have a major role in the company's performance.

Keywords: Sales Growth, Profitability, Liquidity, Performance

\section{PENDAHULUAN}

Perusahaan yang mempunyai kinerja yang baik sudah tentu akan mempunyai kelangsungan hidup untuk lebih lama.Karena dengan kelangsungan hidup maka akan mendorong ekonomi menjadi lebih baik dan akan banyak investor yang akan menanamkan modalnya diperusahaan tersebut. Hal ini tidak terlepas dari dengan semakin banyak penjualan maka kelangsungan perusahaan akan semakin langgeng.Selain itu juga perusahaan akan mendapatkan keuntungan yang didapat akan menjadikan modal selanjutnay.Ini juga tidak terlepas dari likuiditas khusus untuk kemampuan membayar hutang dalan jangka pendek.Karena dengan ketidakmampuan membayar hutang maka akan menjadikan perusahaan akan terlikuid.Sehingga akan menghambat kinerja perusahaan.Maka dari itu dengan adanya kinerja maka akan terbangun dengan baik perusahaan tersebut. Kinerja perusahaan terbangun dengan baik akan terlihat dari laporan keuangan ditiap tahunnya.Menurut IAI kinerja keuangan adalah kemampuan perusahaan dalam mengelola dan mengendalikan sumberdaya yang dimilikinya. Kinerja keuangan terkait salah satunya dengan pertumbuhan penjualan dengan diproksi growth sedangakan pada profitabilitas yang digunakan adalah ROA/Return On Assets,sedangkan likuiditas dengan proksi Current Rasio/CR.Keberhasilan suatu perusahaan akan tercapai karena tindakan atau kegiatan memanage akan prestasi dari pihak manajemen.

Definisi Growth menurut (Kasmir 2014) adalah sebagai berikut Rasio pertumbuhan (growth Ratio) merupakan rasio yang menggambarkan kemampuan perusahaan dalam mempertahankan posisinya di dalam indutri dan dalam perkembangan 
ekonomi secara umum.Rasio pertumbuhan ini dilihat dari berbagai segi sales (penjualan),earning after tax (EAT),laba per lembar saham ,dividen per lembar saham, dan harga pasar perlembar saham.Rasio ini terdiri dari kenaikan penjualan,kenaikan laba bersih ,earning per share dan kenaikan deviden per share.

Laporan keuangan yang disajikan oleh perusahaan dalam beberapa kurun waktu dapat digunakan untuk memprediksi laba atau dividen diwaktu yang akan datang. Dari sudut pandang investor analis laporan keuangan dapat digunakan sebagai alat prediksi prospek masa depan perusahaan tersebut. Sementara itu dari sudut pandang manajemen selain alat prediksi antisipasi masa depan, juga sebagai dasar untuk perencanaan tindakan terhadap faktorfaktor kunci yang sering mempengaruhi peristiwa pada masa lalu sebagai pedoman kedepan.

Sifat dan Keterbatasan Laporan Keuangan

Dalam Ikatan Akuntan Indonesia secara terperinci menjelaskan tentang sifat dan keterbatasan laporan keuangan sebagai berikut:

1. Laporan keuangan yang bersifat sejarah yang tidak lain merupakan kejadian-kejadian yang lewat,maka terdapat keterbatasan.

2. Laporan keuangan bersifat umum dan bukan untuk memenuhi kebutuhan tiap-tiap pemakai.

3. Laporan keuangan itu sebagai hasil pemakaian setelah timbulnya hak dan kewajiban dalam akuntansi. Dalam proses penyusunannya tidak terlepas dari penaksiran dan pertimbanganpertimbangan.
4. Laporan keuangan lebih menekankan bagaimana keadaan sebenarnya peristiwa-peristiwa dilihat dari sudut ekonomi daripada berpegang pada formilnya.

Analisis Ratio Keuangan

Ada dua cara dalam menilai rasio keuangan agar lebih berarti :

1. Menilai rasio keuangan antar waktu (sebaiknya waktu yang cukup lama, misal 5 tahun agar dapat diketahui arah pergerakannya)

2. Membandingkan rasio keuangan perusahaan dengan rasio industri. Penilaian ini akan dapat menilai perusahaan apakah lebih baik atau tidak dibandingkan dengan pesaing kita.

Rasio likuiditas ( Liquidity Ratio ) merupakan rasio yang menggambarkan kemampuan perusahaan dalam memenuhi kewajiban (utang) jangka pendek. Artinya apabila perusahaan ditagih, perusahaan akan mampu untuk memenuhi utang tersebut, terutama utang yang sudah jatuh tempo. Dengan kata lain ,rasio likuiditas berfungsi untuk menunjukkan atau mengukur kemampuan perusahaan dalam memenuhi kewajibannya yang sudah jatuh tempo ,baik kewajiban kepada pihak luar perusahaan (likuiditas badan usaha) maupun didalam perusahaan (likuiditas perusahaan).

\begin{tabular}{ccr} 
Rasio & \multicolumn{2}{c}{ Profitabilitas } \\
merupakan rasio untuk menilai
\end{tabular} kemampuan perusahaan dalam mencari keuntungan. Rasio ini juga memberikan ukuran tingkat efektivitas manajemen suatu perusahaan. Hal ini ditunjukkan oleh laba yang dihasilkan dari penjualan dan pendapatan investasi. Intinya adalah penggunaan rasio ini menujukkan efisiensi perusahaan. Penggunaan rasio profitabilitas dapat dilakukan dengan menggunakan perbandingan antara 
berbagai komponen yang ada dalam laporan keuangan, terutama laporan keuangan neraca dan laba rugi. Tujuannya adalah agar terlihat perkembangan perusahaan dalam rentang waktuu tertentu, baik penurunan atau kenaikan,sekaligus mencari penyebab perubahan tersebut. Jenis-jenis Rasio

Profitabilitas sesuai dengan tujuan yang hendak dicapai , terdapat beberapa jenis rasio profitabilitas yang digunakan. Masing-masing jenis rasio profitabilitas digunakan untuk menilai serta mengukur posisi keuangan perusahaan dalam suatu periode tertentu atau untuk beberapa periode.Penggunaan seluruh atau sebagian rasio profitabilitas tergantung dari kebijakan manajemen. Jelasnya, semakin lengkap jenis rasio yang digunakan,semakin sempurna hasil yang akan dicapai, artinya pengetahuan tentang kondisi dan posisi profitabilitas perusahaan dapat diketahui secara sempurna.

Hasil pengukuran kinerja perusahaan mengetahui baik atau tidaknya kondisi keuangan perusahaan dilihat dari standard Industri yang ditetapkan dalam setiap jenis rasio keuangan yang ada, dari pengukuran Rasio kita dapat melihat kondisi posisi keuangan perusahaan seperti yang terlihat dalam tabel Berikut ini :

\begin{tabular}{lll}
\hline No & \multicolumn{1}{c}{$\begin{array}{c}\text { Jenis } \\
\text { Rasio } \\
\text { Net Profit }\end{array}$} & $\begin{array}{c}\text { Standard } \\
\text { Industri }\end{array}$ \\
$20 \%$ \\
$\mathbf{2}$ & $\begin{array}{l}\text { margin } \\
\text { Return on } \\
\text { investment }\end{array}$ & $30 \%$ \\
$\mathbf{3}$ & $\begin{array}{l}\text { Return on } \\
\text { Equity }\end{array}$ \\
$\mathbf{4}$ & $\begin{array}{l}\text { Fixed asset } \\
\text { turn over }\end{array}$ \\
\hline
\end{tabular}

$5 \quad$ Total asset 2 kali turn over

Sumber : Analisis Laporan Keuangan , Kasmir (2014)

Berdasarkan penelitian sebelumnya (Naray and Mananeke 2015) Pertumbuhan Penjualan tidak memiliki pengaruh signifikan terhadap Struktur Modal. Struktur Aktiva terbukti berpengaruh negatif terhadap Struktur Modal. Ukuran Perusahaan memiliki pengaruh negatif yang signifikan terhadap Struktur Modal.

Penelitian selanjutnya (Suweta and Dewi 2016)pertumbuhan penjualan berpengaruh positif dan signifikan terhadap struktur modal (DER), struktur aktiva berpengaruh positif dan signifikan terhadap struktur modal (DER), dan pertumbuhan aktiva berpengaruh positif dan tidak signifikan terhadap struktur modal (DER).

maka perumusan hipotesis yang dibuat oleh peneliti adalah:

1.Pertumbuhan penjualan berpengaruh terhadap kinerja hero supermarket Tbk..

2.Profitabilitas berpengaruh terhadap kinerja hero supermarket Tbk..

3. Likuiditas berpengaruh terhadap kinerja hero supermarketTbk..

4.Pertumbuhan penjualan,profitabilitas dan likuiditas berpengaruh terhadap kinerja Hero SupermarketTbk..

\section{METODE PENELITIAN}

Populasi yang diambil dalam penelitian ini adalah hero supermarket yang sudah terdaftar di Bursa Efek Indonesia ( BEI ). Sampel yang digunakan perusahaan menggunakan metode pruposive sampling yaitu teknik 
pengambilan sampel sumber data dengan pertimbangan tertentu.,Sugiyono (2011:126). Dan pertimbangan yang digunakan adalah sebagai berikut : 1.Hero supermarket yang terdaftar di Bursa Efek Indonesia (BEI) tahun 20162018

2.Menyajikan laporan keuangan yang terlampir di tahun 2016-2018.

\section{Teknik Pengumpulan Data}

Teknik Pengumpulan data dalam penelitian ini adalah teknik dokumentasi yaitu dengan cara mengumpulkan data sekunder yang diperoleh dari berbagai sumber. Dalam penelitian ini penulis mengumpulkan data sekunder berupa laporan keuangan tahunan pada hero supermarket yang telah terdaftar di Bursa Efek Indonesia melalui situs resmi BEI www.idx.co.id .

\section{Teknik analisis data}

Teknik analisis data yang digunakan dalam penelitian ini dua adalah:Analisis Kualitatif adalah data yang didapatkan akan dianalisis dengan penilaian teoritis dan logis sesuai dengan pembuktian secara kuantitatifnya. Analisis Kuantitatif adalah data yang dianalisis secara pembuktian angka angka sesuai dengan data yang di dapat dalam penelitian.

\section{Variabel Penelitian}

Variabel yang digunakan dalam penelitian ini adalah Pertumbuhan Penjualan,ROA dan Current Rasio terhadap Kinerja sebagai berikut:

1).Pertumbuhan Penjualan

Meningkatnya penjualan dibandingkan dengan total penjualan secara keseluruhan

2).Return On Assets (ROA)

merupakan rasio yang menunjukkan seberapa besar kontribusi assets dalam menciptakan laba bersih

$$
\mathrm{ROA}=\frac{\text { Laba setelah pajak }}{\text { Total Assets }} \times 100 \%
$$

3).Current Ratio (CR)

Current ratio adalah alat yang digunakan untuk mengukur kemampuan perusahaan dalam membayar kewajiban jangka pendek.

$$
\mathrm{CR}=\frac{\text { Aktiva Lancar }}{\text { Utang Lancar }}
$$

HASIL DAN PEMBAHASAN

Berdasarkan penelitian didapatkan hasil sebagai berikut :

\section{Uji Hipotesis}

Hasil uji regresi linier berganda yang disajikan pada tabel 1 berikut ini:

\begin{tabular}{|c|c|c|c|c|c|c|}
\hline \multirow[t]{2}{*}{ Model } & & \multicolumn{2}{|c|}{ Unstandardized Coefficients } & \multirow{2}{*}{$\begin{array}{c}\text { Standardized } \\
\text { Coefficients } \\
\text { Beta }\end{array}$} & \multirow[t]{2}{*}{$\mathrm{t}$} & \multirow[t]{2}{*}{ Sig. } \\
\hline & & B & Std. Error & & & \\
\hline 1 & (Constant & 428.640 & 264.625 & & 1.506 & .201 \\
\hline & GROWTH & .126 & .013 & .046 & .229 & .023 \\
\hline & ROA & 6.852 & .174 & .546 & 2.231 & .001 \\
\hline & $\mathrm{CR}$ & 1.023 & .143 & .361 & .291 & .002 \\
\hline
\end{tabular}

Tabel 1

Hasil Uji Regresi Linier Berganda 
Dari tabel diatas didapat persamaan regresi linier berganda sebagai berikut:

Kinerja $=428.640+0.126 \mathrm{X} 1+6.852 \mathrm{X} 2+$ $1.023 \mathrm{X} 3$

Interprestasi persamaan diatas sebagai berikut:

1.Nilai kontantan sebesar 428.640 yang artinya jika nilai Growth,ROA dan CR memiliki nilai sama dengan nol maka nilai kinerja sebesar 428.640

2.Nilai Growth sebesar 0.126 Dengan koefisien positif yang artinya setiap Growth meningkat satu satuan maka kinerja akan mengalami peningkatan sebesar 0.126 satuan dengan asumsi bahwa variabel bebas lainnya dianggap konstan.

3.Nilai ROA sebesar 6.852 Dengan koefisien positif yang artinya setiap ROA meningkat satu satuan maka Kinerja akan mengalami peningkatan sebesar 6.852 satuan dengan asumsi bahwa variabel bebas lainnya dianggap konstan.

4.Nilai CR sebesar 1.023 Dengan koefisien positif yang artinya setiap CR meningkat satu satuan maka Kinerja akan mengalami peningkatan sebesar 1.023 satuan dengan asumsi bahwa variabel bebas lainnya dianggap konstan.

\section{Tabel 2}

\section{Model Sumary}

\begin{tabular}{lrrrr}
\hline Model & $\mathrm{R}$ & $\mathrm{R}$ Square & Adjusted R Square & Std. Error of the Estimate \\
1 & $.882^{\mathrm{a}}$ & .831 & .810 & 187.240 \\
Sumber : data diolah 2021 & & & \\
\hline
\end{tabular}

Dari tabel 2 maka hasil $\mathrm{R}$ - Square diperoleh sebesar 0,831 yang akan diubah menjadi prosentase sebesar $83,1 \%$ yang artinya Growth,ROA dan CR memberikan pengaruh terhadap Kinerja sedangkan sisanya dipengaruhi oleh faktor lain yang tidak diteliti oleh peneliti

\section{KESIMPULAN}

Berdasarkan penelitian di dapatkan hasil sebagai berikut :

1.Pertumbuhan penjualan dengan proksi growth berpengaruh terhadap kinerja hero supermarket

2.Profitabilitas dengan proksi ROA berpengaruh terhadap kinerja hero supermarket

3. Likuiditas dengan proksi Current Rasio berpengaruh terhadap kinerja hero supermarket

\section{DAFTAR PUSTAKA}

Naray, A. R., and L. Mananeke. 2015. "PENGARUH PERTUMBUHAN

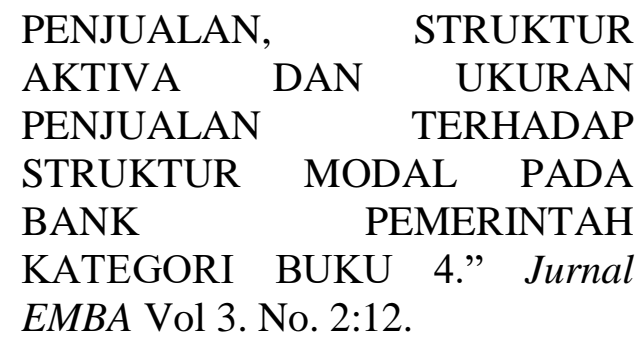

Fahmi, Irham,2010. Analisis Laporan Keuanga, Edisi Pertama. Alfabeta. Bandung.

Hery. 2015. Analisis Laporan Keuangan, PT Buku Seru. Cet 1. Yogyakarta.

Kasmir. 2014. Analisis Laporan Keuangan,

Edisi Pertama (Revisi). PT RajaGrafindo Persada. Jakarta.

Kuncoro, Mudrajad. 2011. Metode Kuantitatif, Edisi Empat. Unit Penerbit dan Percetakan Sekolah Tinggi Ilmu Manajemen. Yogyakarta

Munawir. 2010. Analisa Laporan Keuangan, Edisi Keempat. Liberty. Yogyakarta.

Milyati,rina .(2017).Uji parsial current rasio,debt to equity rasio dan 
inventory turnover terhadap return on assets pada perusahaan makanan dan minuman yang terdaftar di bursa efek indonesia. Jurnal ilmiah gema ekonomi:7(1),951-964.

Milyati,rina.(2017).Pengaruh Dominan current ratio,debt to assets ratio,total assets turnover terhadap return on equity pada perusahaan makanan dan minuman di bursa efek Indonesia .Optimum: Jurnal ekonomi dan pembangunan:7(1) 27 -38 .

Milyati ,rina.(2016).Pengaruh Dominan cash ratio dan debt to assets rastio terhadap Return on Equity dan return on assets pada perusahaan transportasi di bursa efek Indonesia,Jurnal Manajemen Magister Darmajaya:2(1),95-104.

Milyati ,rina.(2019).Analisis pertumbuhan penjualan,profitabalitas dan likuiditas terhadap kinerja perusahaan otomotif yang terdaftar di bursa efek indonesia.Gema Jurnal Gentiaras Manajemen dan Akuntansi:11(2) 148-157.

Pura, Rahman. 2013. Pengantar Akuntansi 1 : Pendekatan Siklus Akuntansi, Edisi Pertama. Erlangga. Jakarta.

Ribo,Agustinus.2013.Analisis Laporan Keuangan untuk menilai Kinerja Keuangan Perusahaan Telekominikasi Yang Terdaftar Di Bursa Efek Indonesia (Studi Pada PT Telekomunikasi Indonesia $T B K$ ), Skripsi ,Fak. Ekonomi Dan Bisnis,Universitas Hasanuddin ,Makasar

Sartono,A.2001.Manajemen Keuangan: Teori dan Aplikasi.Edisis

Keempat.Cetakan

Pertama.Yogyakarta:BPFE

Sugiono,2014.Metode Penelitian

Kuantitatf,Kualitatif dan

$R \& D$, Bandung.CV Alfabeta
Suweta, Ni Made Novione Purnama Dewi, and Made Rusmala Dewi. 2016. "PENGARUH PERTUMBUHAN PENJUALAN, STRUKTUR AKTIVA, DAN PERTUMBUHAN AKTIVA TERHADAP STRUKTUR MODAL." E-Jurnal Manajemen Unud Vol. 5 No. 8. 